\title{
STRUCTURAL DEVELOPMENT OF MIGMATITES NEAR SKÅLDÖ, SOUTHWEST FINLAND
}

\author{
A. M. HOPGOOD, D. R. BOWES and J. ADDISON
}

\begin{abstract}
HOPGOOD, A. M., BOWES, D, R, and ADDISON, J. 1976: Structural development of migmatites near Skåldö, southwest Finland. Bull. Geol. Soc. Finland 48, 43-62.
\end{abstract}

The migmatites of the Skåldö area show the effects of an extensive polyphase deformational history at relatively deep crustal levels during the Svecokarelian episode. Despite the complexity of the fold patterns it is possible to establish a deformational sequence into which the many phases of igneous emplacement in the rocks can be placed. There are at least seven successive fold sets and a number of phases of both basic and acidic igneous activity as well as the effects of metamorphism which reached a peak, under amphibolite facies conditions, early in the deformational history. Taken together the various features comprise a complex framework which can be used as a basis for comparison and correlation with the products of the Svecokarelian orogenic episode in other parts of the Baltic Shield. The characteristics of these migmatites in this classic area, viz. their "mixed» aspect as described by J. J. Sederholm, is shown to result from their extensive deformational, metamorphic and igneous history in which tectonic and igneous activity played prominent roles.

A. M. Hopgood, Department of Geology, University of St. Andrews, Fife, KY 16 9TS, Scotland.

D. R. Bowes and J. Addison, Department of Geology, University of Glasgow, G12 8QQ, Scotland.

\section{Introduction}

In southwest Finland, a classic region for migmatites (Sederholm 1967), the rocks represent a relatively deep level in the Svecokarelian orogenic belt which, elsewhere in Finland where metasedimentary schists predominate, has been shown to have an extensive polyphase deformational and metamorphic history (Gaál et. al. 1975; Bowes 1975; in press). However, from the detailed illustrations and descriptions of Sederholm (1967) it is evident that the migmatites also have undergone popyphase deformation and multiple igneous injection.

To study this deformational, metamorphic and igneous history, members of the Glasgow University Exploration Society spent four weeks in the field around Skåldö on Skärlandet, and some of the smaller adjacent islands south of Tammisaari (Fig. 1; King and Grey 1975). The work has confirmed that the rocks, including many which are migmatitic, preserve a consistent record of 


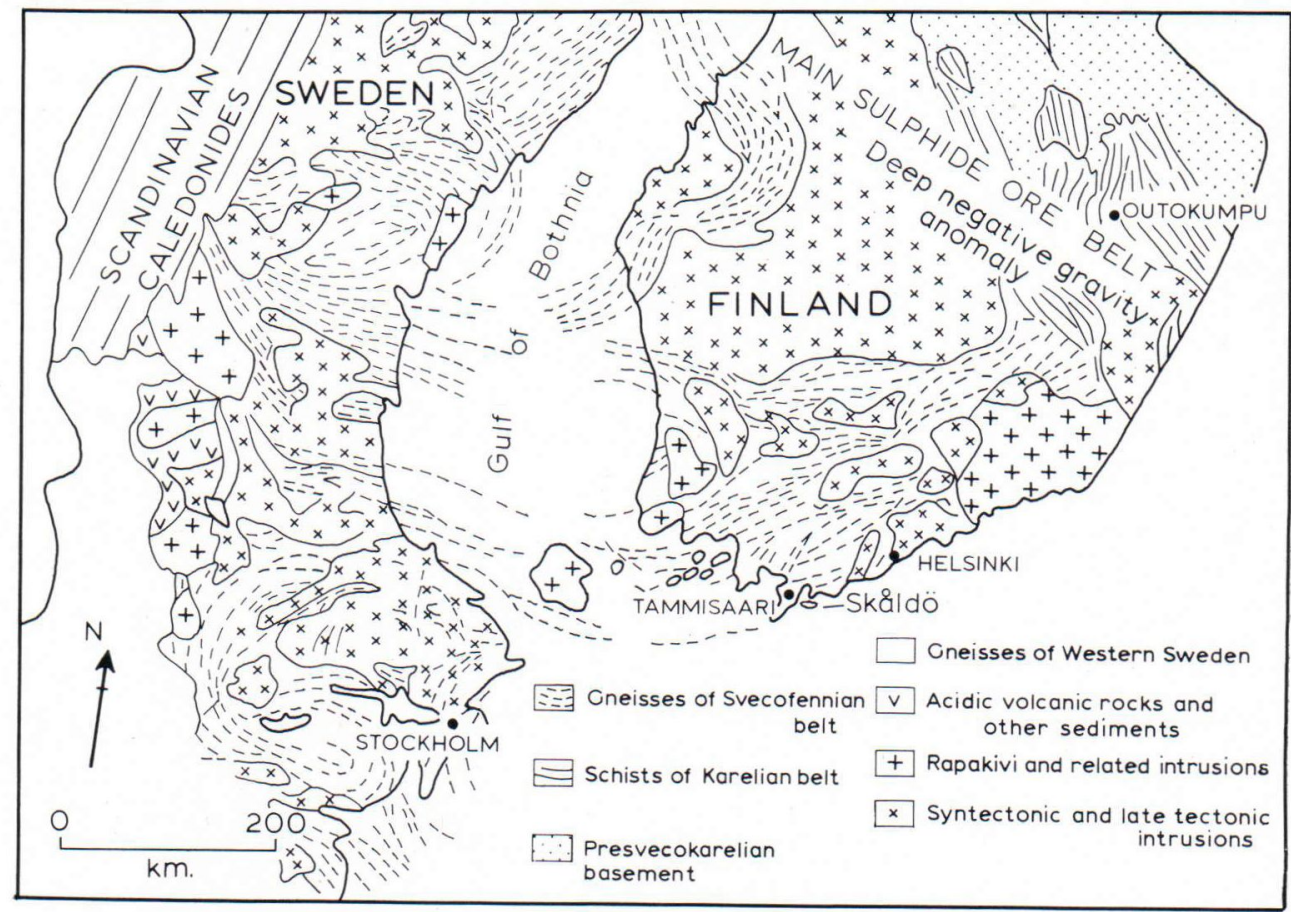

Fig. 1. Map of part of the Svecokarelian belt (after Welin, 1970) showing location of area studied.

a deformational, metamorphic and intrusive history of considerable complexity (Figs. 2, $3,4)$. While the complexity is such that further work is needed both locally and regionally to complete the picture, a general pattern of structural development has been established. This is presented as a contribution to knowledge of the Svecokarelian belt and as a framework within which to discuss the origin of the migmatites, particularly as many studies relating to the genesis of this group of rocks have been laboratory rather than field oriented (Mehnert 1968).

Exposure, which is generally very good, is restricted mainly to narrow and discontinuous strips three to four metres wide along the shore lines. These are nevertheless extremely clean, especially on the northern sides of the islands facing the direction of Pleistocene ice movement. Inland outcrop is limited to iso- lated hillocks where the quality of the exposure is reduced in most cases by thick lichen cover which limits its value for the investigation of small scale deformational features and intricate intrusive relationships.. In some places however, it is possible to peel off the vegetation cover to expose particularly clean rock faces.

The regional structural pattern of much of southwestern Finland has been published by Härme (1960) together with the nature and distribution of the various rock units. Further detail is provided by the Geological Survey of Finland 1:100,000 Sheet 2013 - Jussarö (Laitala 1973). Amphibolite facies metasediments and gneisses occur together with a wide variety of igneous rocks that range from ultrabasic to acidic in composition and which predominate over the metasedimentary units (Härme 1965, Appendix 1). Most of the 

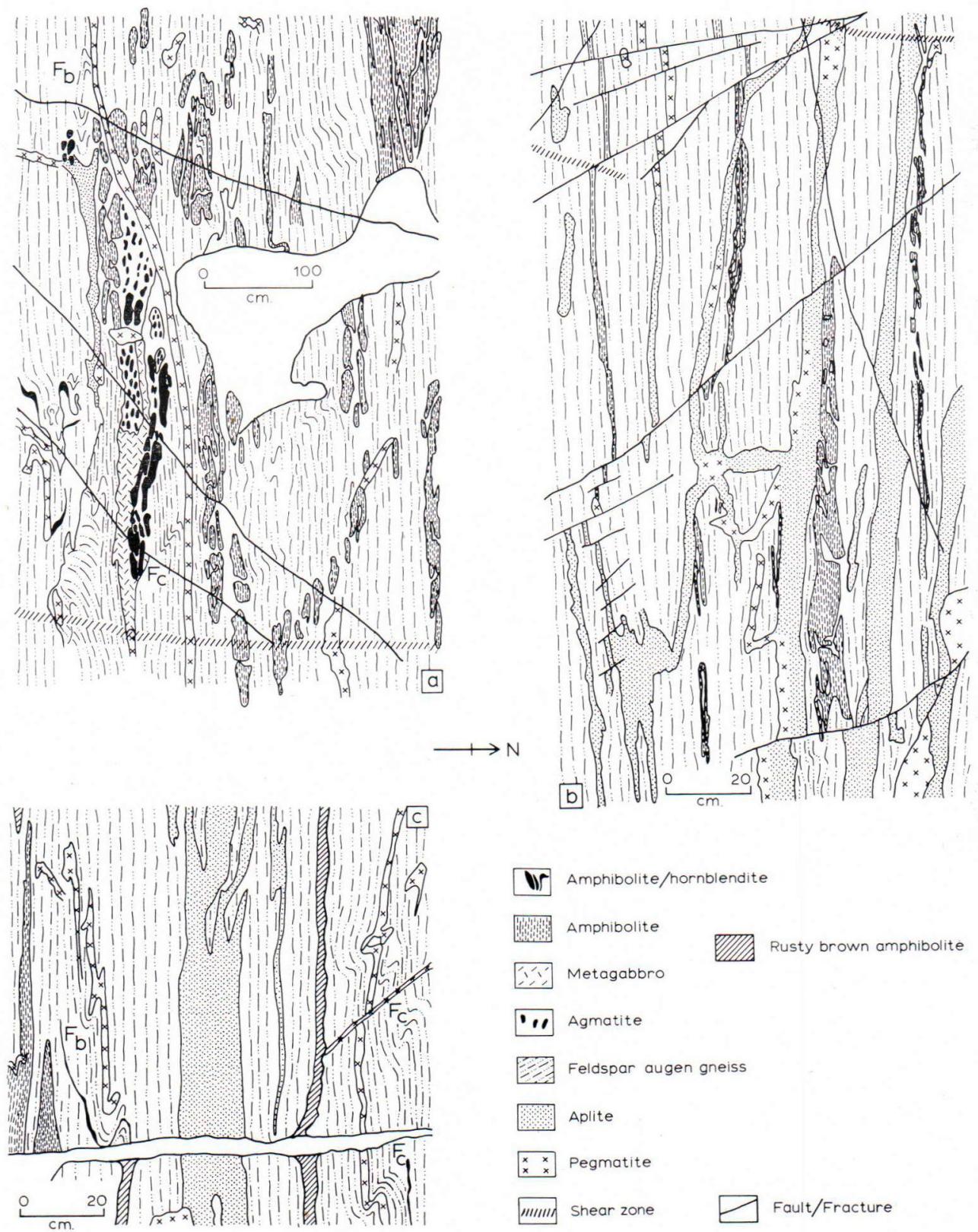

Fig. 2. a, b, c. Relationships between various basic to acidic intrusions and deformation. Baggöhamn near the kiosk, Skärlandet.

rock types have been affected in the course of the deformational and metamorphic history and in consequence display a considerable diversity of structural relationships.
Although repeated intrusion, metamorphism and deformation has compounded the complexity of the Skåldö migmatites, the investigation has nevertheless shown that it 

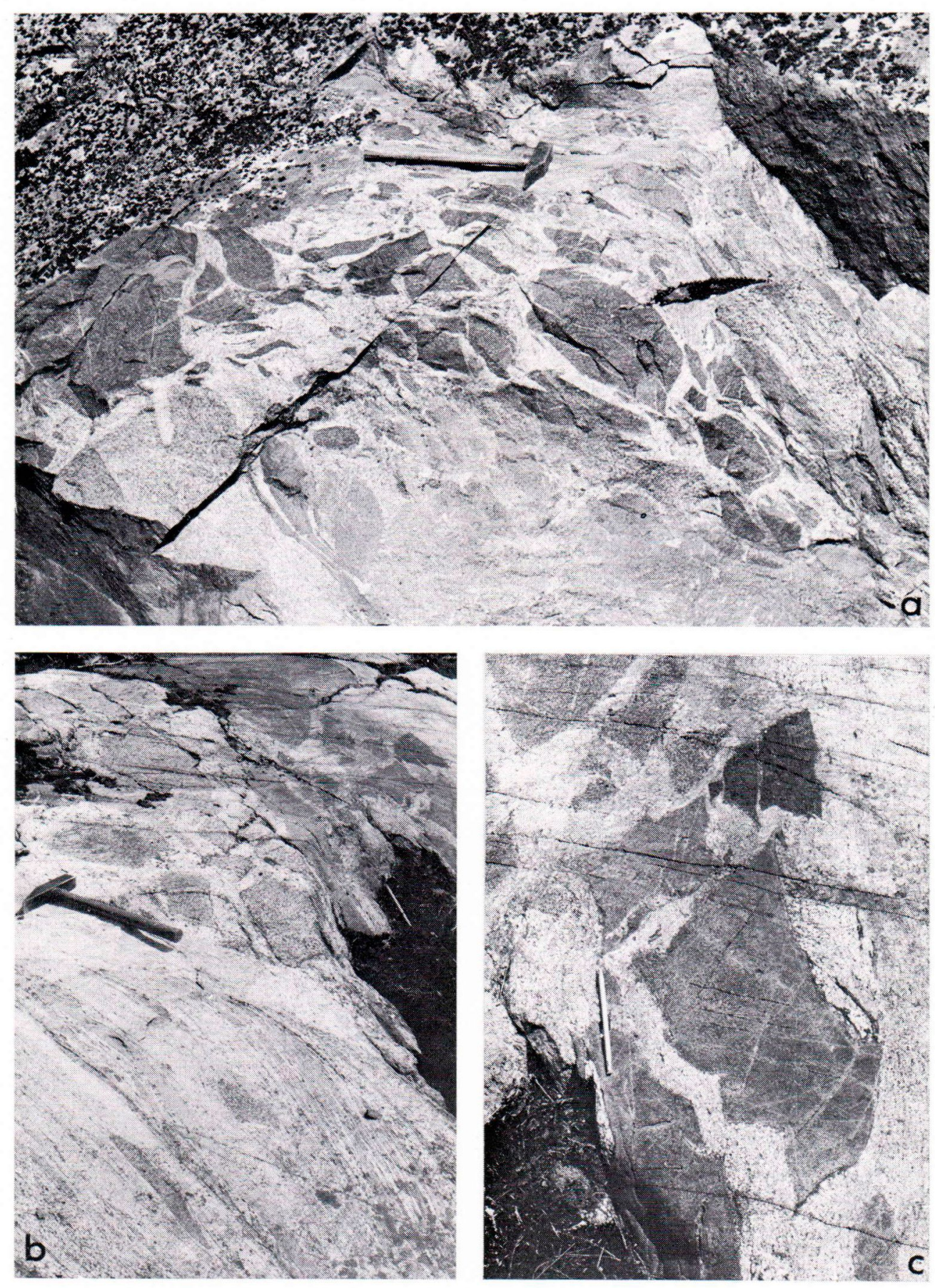

Fig. 3. Agmatites showing the development of foliation in the matrix. Road between Skåldö and Baggöhamn, Skärlandet. 


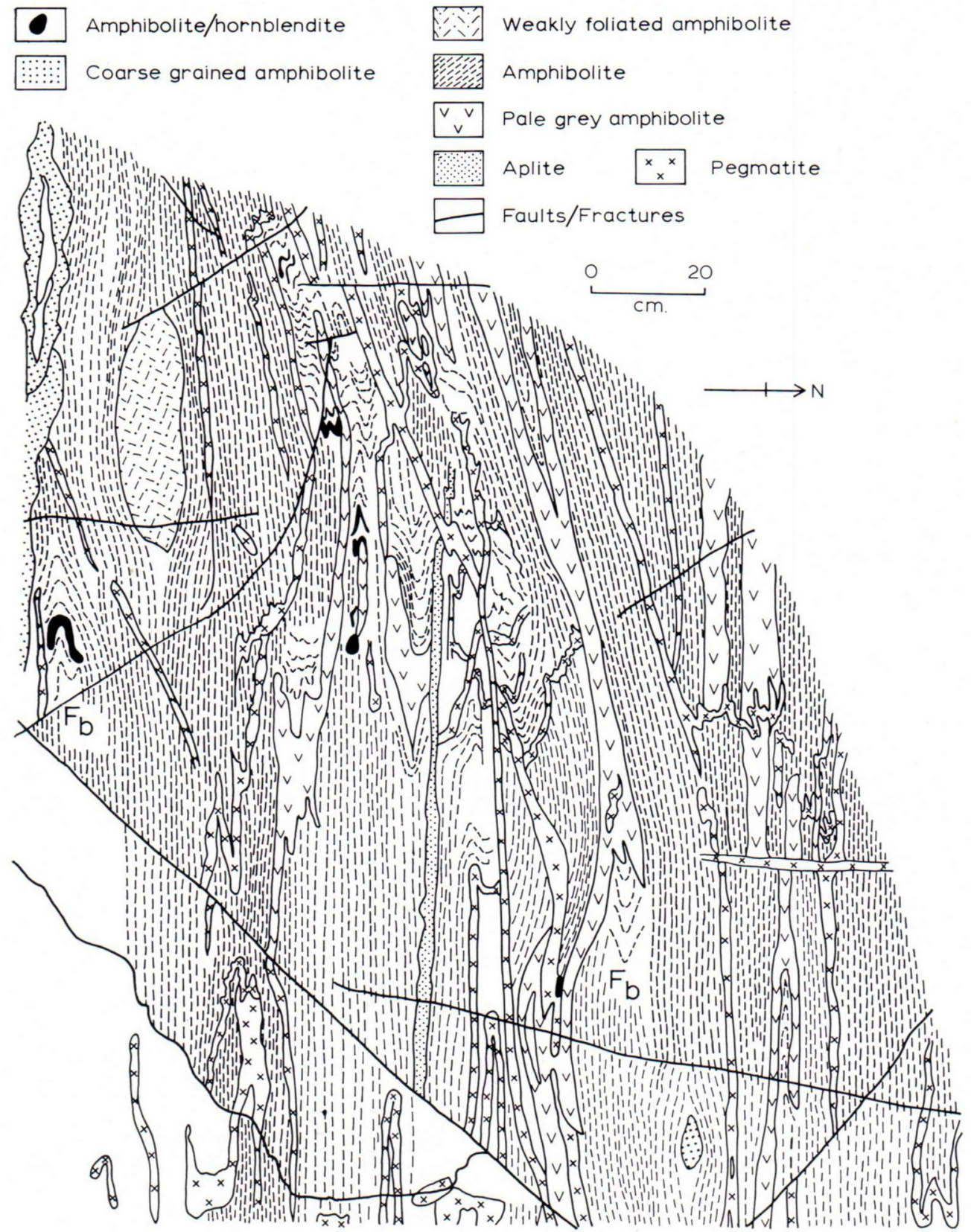

Fig. 4. Relationship between amphibolites, aplite, pegmatite veins, foliation and folds. North shore of Ängholmen at the west end, east of Svartholm.

is possible to establish a deformational sequence within them. Therefore they are amenable to investigation based on the inter- pretation of the relationship of small-scale structures to one another and to igneous and metamorphic phenomena and this provides 
another way in which it is possible to throw light on the history of these classic rocks. The approach employs techniques previously used successfully in highly deformed terrains in the Highlands and islands of Scotland (Hopgood and Bowes 1972) and elsewhere in the world (Hopgood 1971, 1973). The method is based on two fundamental principles of geology, namely that (1) deformed structures are older than those which deform them and (2) cross-cutting features are later than those which they cut. Structures and igneous intrusions so found to post-date others can be traced, using characteristic features already established such as orientation, style and mineral growth, to other outcrops where they, in turn, are affected by later structures or cross-cut by later intrusions. Thus a structural sequence can be built up in the rocks and related to metamorphic and igneous events.

As a result of the present preliminary investigation a sequence involving some of the principal events affecting the migmatites has been drawn up and is presented here as an indication of what can be determined regarding the history of these rocks by using the relationships of small-scale structures including minor intrusions. While the list of events (Table 1) is not regarded as being comprehensive, the events are considered to be in sequence, if not necessarily consecutive.

The deformational events producing the structures described are designated $\mathrm{D}_{\mathrm{a}-\mathrm{n}}$ and known equivalent fold sets produced by these events are referred to as $F_{a-n}$. The structures resulting from each of the major deformational events are described separately

Table 1: Outline of sequence of events in migmatites, Skåldö

1) A series of events (sedimentary, and igneous) leading to the establishment or a lithologically layered succession (Figs. 2, 4).

2) Deformation $\left(\mathrm{D}_{a}\right)$ responsible for the development of the present isoclinal, intrafolial folds $\left(\mathrm{F}_{\mathrm{a}}\right)$. Syntectonic mineral growth with production of preferred orientation of minerals parallel to the fold axial planes. This was probably the main gneiss-forming event (Fig. 6).

3) Emplacement of basic minor intrusions, now amphibolites. Intrusion of aplitic minor intrusions (Figs. 2, 4).

4) Deformation $\left(D_{b}\right)$ responsible for the development of tight folds with axial planes parallel to the main foliation $\left(\mathrm{F}_{\mathrm{b}}\right)$. Both flexure and slip were involved (Fig. 7).

5) Emplacement of granite, pale cement-grey amphibolites and discordant quartzofeldspathic pegmatites with a more or less northerly trend (Fig. 3 a).

6) Onset or continuation of foliation slip $\left(\mathrm{D}_{\mathrm{b}}{ }^{\prime}\right)$ to produce slip folds ( $\left.\mathrm{F}_{\mathrm{b}}{ }^{\prime}\right)$ in the cross-cutting intrusions. This or related movement appears to have continued throughout the deformational sequence (Fig. 8).

7) Deformation $\left(\mathrm{D}_{\mathrm{c}}\right)$ responsible for the development of asymmetrical folds $\left(\mathrm{F}_{\mathrm{c}}\right)$ with $\mathrm{SE}$-trending axial traces and parallel pegmatite (Fig. 9).

8) Deformation $\left(\mathrm{D}_{d}\right)$ responsible for the development of asymmetrical folds $\left(\mathrm{F}_{\mathrm{d}}\right)$ with $\mathrm{NE}$-trending axial traces and parallel pegmatite veins (Fig. 10).

9) Deformation ( $\left.\mathrm{D}_{\mathrm{e}}\right)$ responsible for the development of open folds $\left(\mathrm{F}_{\mathrm{e}}\right)$ with incipient shear and slight pegmatite veining in two directions on their limbs. These may prove to belong to two sets of folds (Fig. 13).

10) Deformation responsible for inclined folds which probably belongs to a position which is relatively early in the deformational sequence and as yet not located.

11) Deformation responsible for the development of more or less symmetrical open folds with subvertical north-trending axial planes and fine axial planar fracture cleavage (Fig. 14).

12) Deformation responsible for NNE- and SSE-trending conjugate shears probably causing northtrending gash veins in response to $\mathrm{N}-\mathrm{S}$ compression after the late folds.

13) Slip parallel to the foliation offsetting the complementary shears. This more brittle deformation appears to be the latest to affect the migmatites. 
with those of the later events, which are generally more weakly expressed, and those of uncertain position in the sequence grouped for description under the heading $\mathrm{D}_{\text {late }}$. Here the degree of confidence with which the order of events can be established both at any one outcrop, and regionally, is less than that for the major events $D_{a-e}$. Letters rather than numbers are used to designate events in the sequence as subsequent work in the surrounding areas may reveal further deformational events. Also in places where flattening and other tectonic activity have not been as extensive as is generally the case, further aspects of the early history may be deciphered in the future. When this further work is done, numbering of events should be more meaningful.

\section{Deformational sequence}

\section{Introduction}

The oldest rocks comprise metasediments (including highly deformed marbles), basic intrusive igneous rocks now largely agmatized, amphibolites and hornblendites (Figs. 2, 3), porphyritic microgranites (Fig. 3) and possibly basic lavas. There is a complex relationship between folding and foliation of at least four sets of basic rocks shown in Fig. 2, as well as with gneiss, aplite and pegmatite. This intricate association is typical of that shown by most of the migmatites in the area and the illustrations show clearly the irregular and lobate form of some of the more highly deformed intrusive bodies as well as the way in which the foliation cuts through the folded remnants of some cross-cutting units (e.g. the large fold in agmatised amphibolite in the bottom right hand corner of Fig. 2 c). The quality of the exposure in places is such that the finest details are clearly displayed so that cross-cutting and cross-folding relationships may be determined with a high degree of confidence.

The porphyritic microgranite, whose emplacement appears to have accompanied, at least in part, the development of some agmatites (Fig. 3), shows effects of flattening and alignment of crystals. Continued flattening resulted in the development of streaky gneiss (Fig. 3 a-right). In places agmatite blocks have resisted flattening with forms that indicate simple separation at the time of igneous injection (Fig. $3 \mathrm{c}$ ). It is in this structural situation that the earliest history of the rocks is likely to be resolved. However, the extent of flattening generally varies from place to place, with strongly foliated rocks representing the effects of extreme flattening (Fig. 3 b-bottom) wrapping around more competent lens-shaped masses. The pattern of zones of high deformation separating areas of much lower deformation appears to be a feature of the whole district.

The alignment and flattening of the phenocrysts begun with the earliest recognized deformation phase $\left(\mathrm{D}_{\mathrm{a}}\right)$, was accentuated by subsequent folding and flattening perpendicular to the dominant foliation as well by shear parallel to the gneissose foliation. With successive emplacement of a number of igneous masses of varying composition and further agmatization (Fig. 5), the resultant rocks have a thoroughly mixed (i.e. migmatitic) aspect (Sederholm 1907). In places there are as many as seven different cross-cutting rock types in various states of deformation and disintegration (Fig. 4). Those migmatites, showing effects of flattening, foliation formation and igneous emplacement, were then deformed several times and intruded by more discrete masses including pale grey amphibolite (Figs. 4, 5 a), aplite and a succession of pegmatites (Fig. 5 b). 

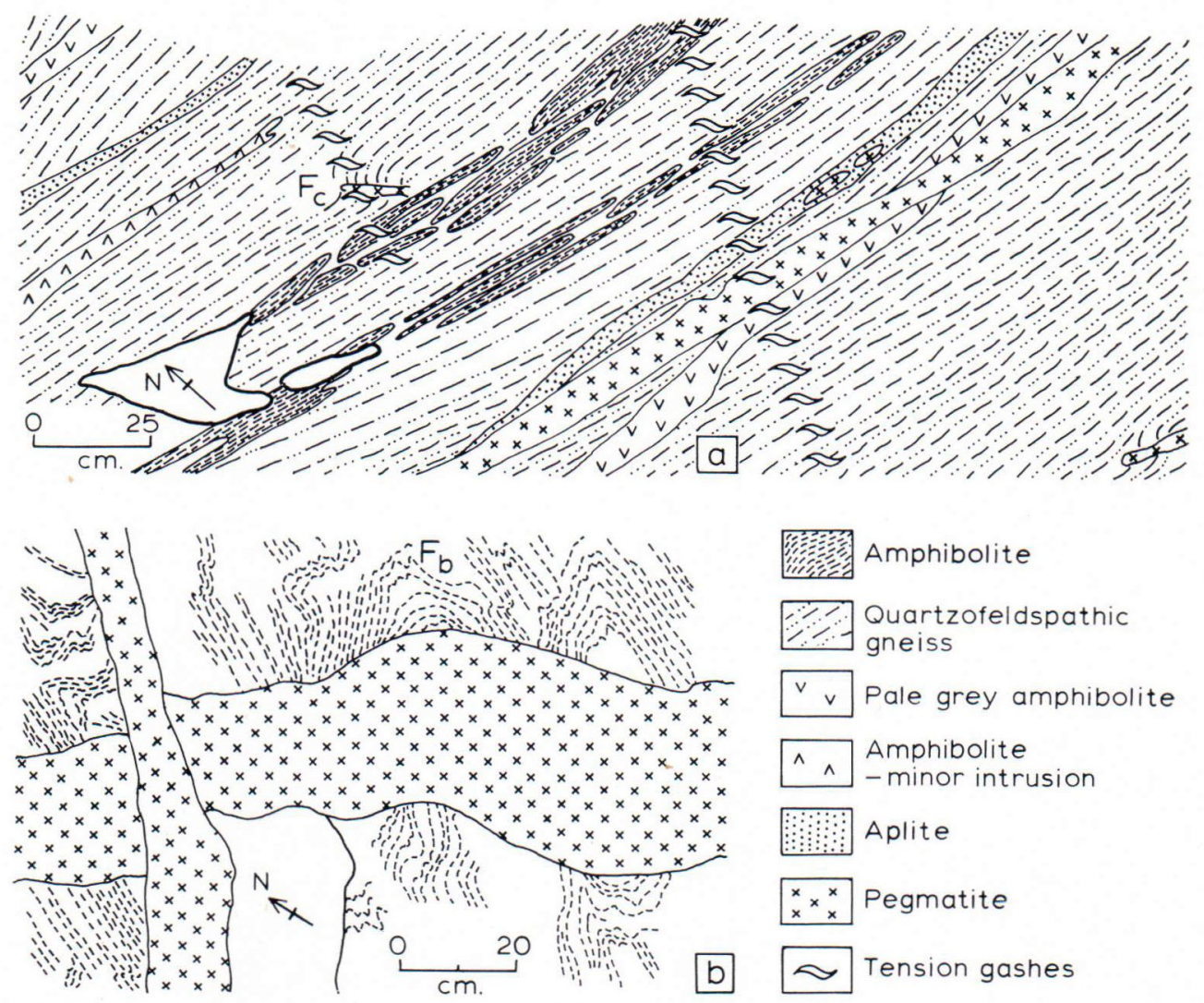

Fig. 5 a. Relationship between amphibolites, aplite, pegmatite, foliation and folds, and cross-cutting tension gash veins. Baggöhamn near the kiosk, Skärlandet, b. Cross-cutting of post- $\mathrm{F}_{b}$ pegmatite veins. Clearing in woods west of road south of Skåldö ferry, Skärlandet.

\section{Deformational phases}

\section{$\mathrm{D}_{\mathrm{a}}$ phase}

The earliest folds identified $\left(\mathrm{F}_{\mathrm{a}}\right)$ are isoclinal structures with attenuated limbs and sharp hinges. These folds, which lie wholly within the foliation (Fig. 6), have been seen on only a small scale, usually just a few $\mathrm{cm}$ long. Most are isolated, either because they are rootless, due to tectonic attenuation of limbs, or because of their geometry and orientation combined with the effects of later folding. In a number of localities the folds are seen to have been folded around tight, sometimes almost symmetrical folds whose axial planes are largely parailel to the foliation (Fig. 6 b). In places the latter folds contain a weakly developed axial planar mineral growth through their hinge zones. The $F_{a}$ folds, however, have the dominant dimensional alignment of minerals cutting their hinge zones and parallel to their axial planes.

Wherever it has been possible to determine the axial orientation of $\mathrm{F}_{\mathrm{a}}$ folds this has been found to be sub-horizontal, suggesting that these small scale folds may be parasitic structures on the limbs of as yet unrecognized large scale isoclinal synformal and antiformal flexures with steep to vertical limbs and subhorizontal hinges. These might well have 



Fig. 6a. Small $\mathrm{F}_{\mathrm{a}}$ fold, looking south. Near the kiosk, Baggöhamn, Skärlandet. b. Parallelism of axial plane of $\mathrm{F}_{\mathrm{a}}$ fold with that of tight $\mathrm{F}_{\mathrm{b}}$ fold which refolds it. Both structures cut by $\mathrm{N}-\mathrm{S}$ quartz filled tension gashes; looking west. West end Ängholmen, north shore. c. Parallelism of axial planes of $\mathrm{F}_{\mathrm{a}}$ and $\mathrm{F}_{\mathrm{b}}$; looking east. Baggöhamn near the kiosk, Skärlandet. 

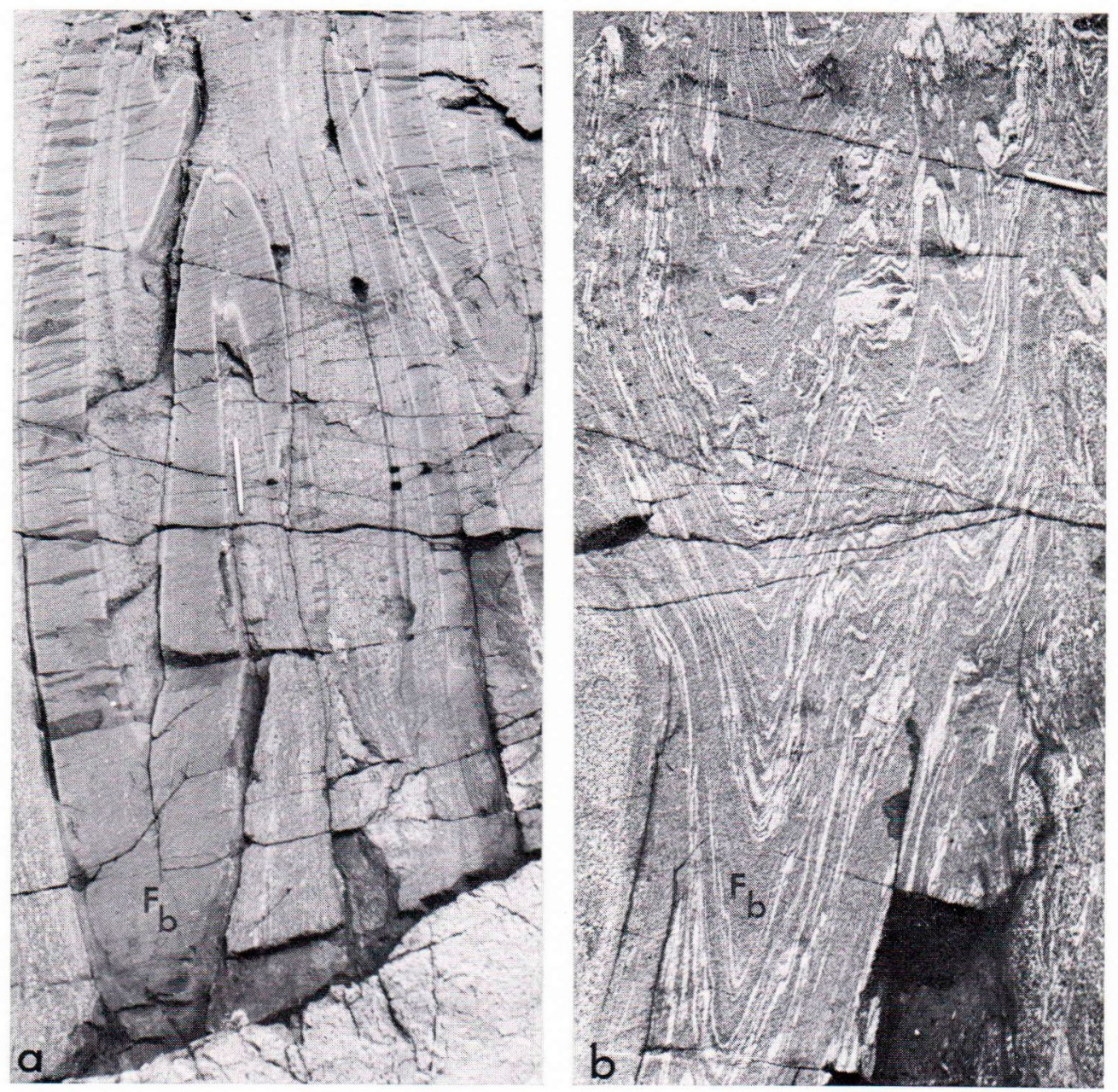

Fig. 7a. Isoclinal $\mathrm{F}_{\mathrm{b}}$ folds; looking east. North shore of Skärlandet opposite Björnholmen. b. $\mathrm{F}_{\mathrm{b}}$ folds; looking west. North shore, west end of Ängholmen.

formed in response to simple horizontal compression in a direction perpendicular to the foliation.

\section{$D_{b}$ phase}

Folds referred to this deformational phase tend to be tight structures which fold the dominant foliation and mineral alignment. They have limbs more or less equally inclined to their axial planes which are themselves parallel to the foliation and this relationship applies even where $\mathrm{F}_{\mathrm{b}}$ folds are markedly asymmetrical (Fig. 6 c). In some cases the structures are isoclinal (Fig. 7 a) but more usually there is an interlimb angle of at least $10-20^{\circ}$ especially in the hinge areas of larger folds where the smaller folds tend to be asymmetrical (Fig. 7 b). Normally they are readily distinguishable from $\mathrm{F}_{\mathrm{a}}$ generation folds because of their geometry and orientation and they can often be seen refolding the typically slender profiles of $\mathrm{F}_{\mathrm{a}}$ intrafolial folds (Fig. 6 b). In those cases 

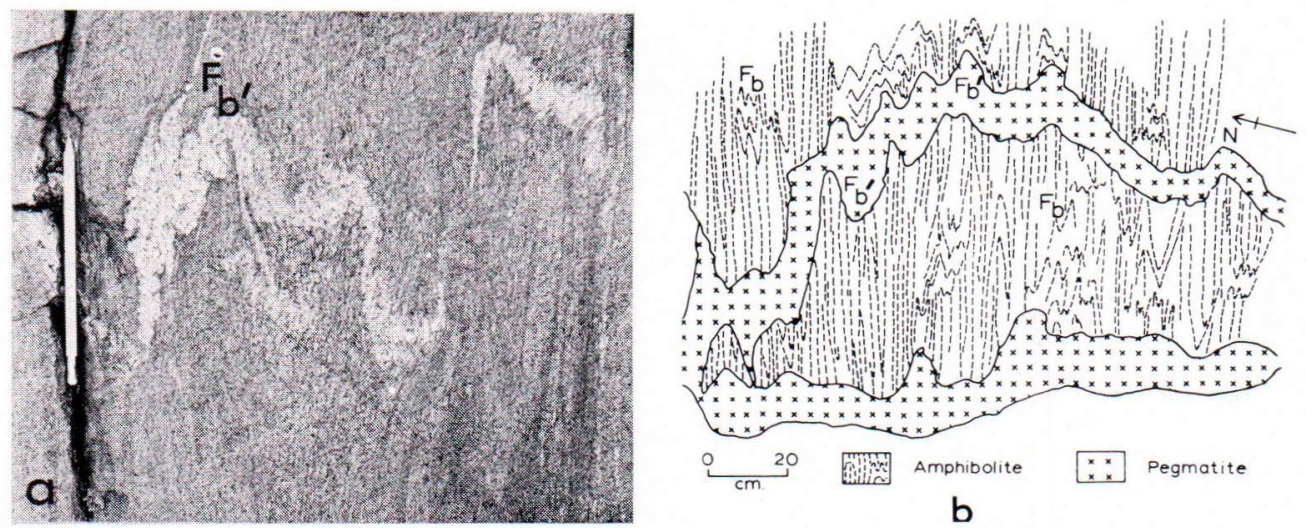

Fig. 8a. Cross-cutting pegmatite vein folded during $\mathrm{D}_{b}{ }^{\prime}$. North shore of Skärlandet opposite Björnholmen. $b$. $F_{b^{\prime}}$ folded pegmatite veins cutting $F_{b}$ folds. Clearing in woods west of road south of Skåldö ferry, Skärlandet.

where the hinge orientation is determinable it is seen that the axes of $\mathbf{F}_{b}$ folds are steeply inclined and this is consistent with development as a result of flexure on inclined axes probably succeeded by simple shear parallel to the foliation which they fold. While the axial planar mineral alignment discerned in $\mathrm{F}_{\mathrm{b}}$ folds is only faint, it may be that the more abvious mineral alignment associated with the $F_{a}$ folds is due to the fact that the axes of these folds are parallel to the outcrops which are normally more or less horizontal. Thus the elongation of minerals and mineral aggregates parallel to the $\mathrm{F}_{\mathrm{a}}$ fold axes is more easily discernible while $F_{b}$ axes on the other hand are steep and mineral elongation parallel to them would not be seen except on steep outcrops which are less common.

The formation of $F_{b}$ folds was at least in part due to slip, and deformation at this time seems to have presaged an extensive period of folding by inclined slip parallel to the main foliation direction. In the course of this deformation successive generations of pegmatite veins and minor intrusions emplaced at high angles to the foliation became folded while at the same time early folds were increasingly more strongly modified. Slip paral- lel to the foliation appears to have affected the migmatites right up to the end of, or close to the end of, the deformational sequence determined and for the limited area studied it seems to have been a dominant feature of the style of tectonism which affected them. The continuance of this shear until late in the deformational sequence undoubtedly accounts for the relatively common occurrence of coaxial-planar folds belonging to this and later generations. As yet no large scale examples of $\mathrm{F}_{\mathrm{b}}$ folds have been recognized.

The deformational episode responsible for the formation of $\mathrm{F}_{\mathrm{b}}$ folds was succeeded by at least two intrusive episodes; the emplacement of porphyritic microgranite associated with agmatisation and the injection of coarse grained pink pegmatite veins, commonly with an approximately $\mathrm{N}-\mathrm{S}$ trend. The latter form one of the means whereby recognition of shear folding later than that causing $F_{b}$ folds is possible and strongly discordant pegmatites emplaced about this time display the effects of shear folding of this type (designated $\mathrm{F}_{\mathrm{b}}{ }^{\prime}$ ). Characteristically $\mathrm{F}_{\mathrm{b}}{ }^{\prime}$ folds have thick hinges and attenuated limbs (Fig. 8 a) and can be seen to have a development independent of the earlier $F_{b}$ folds to whose axial plane they are nevertheless parallel 

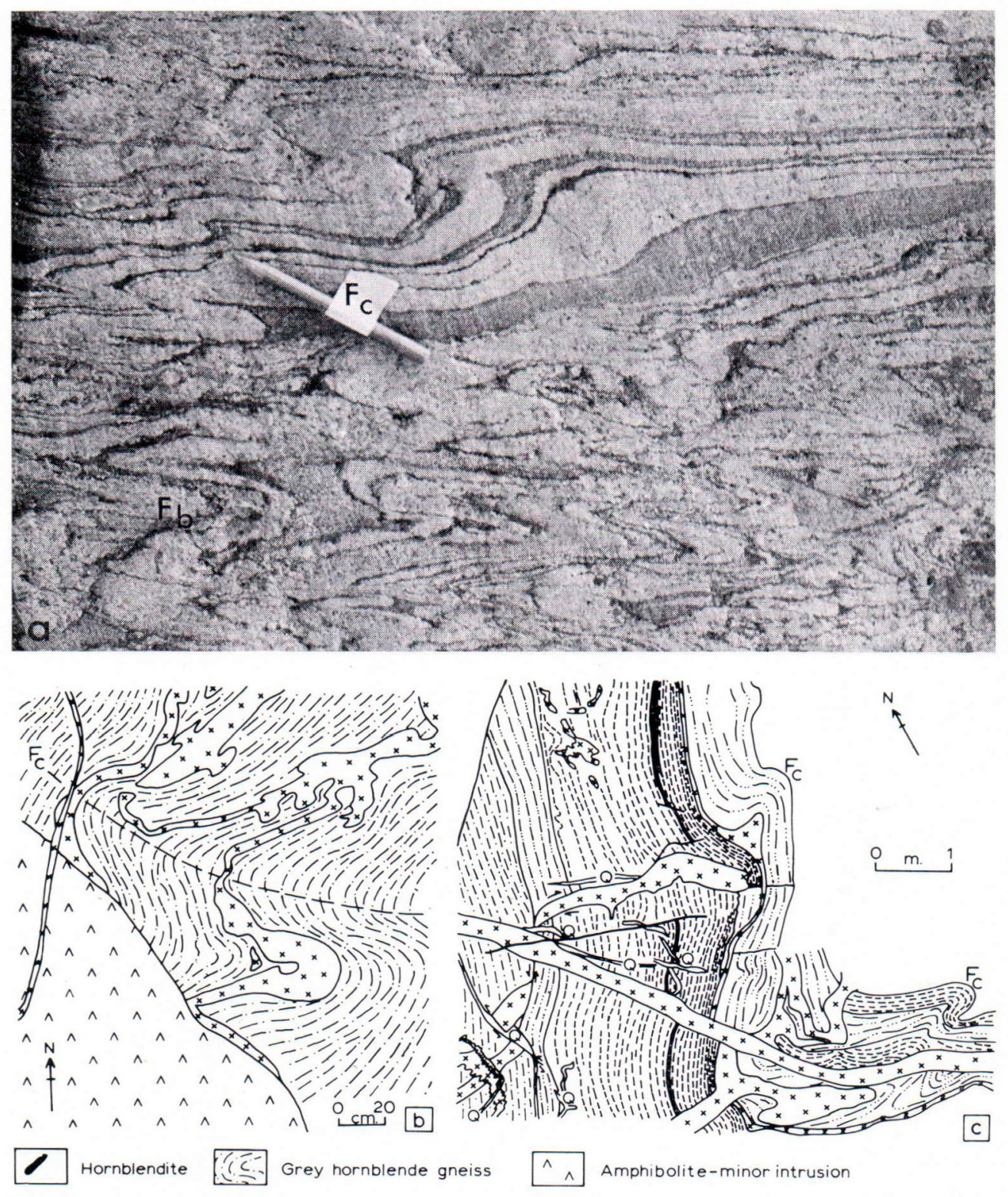

$\wedge \wedge$ Amphibolite-minor intrusion

i! i i i i

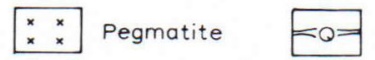

Quartz

Fig. 9a. $\mathrm{F}_{\mathrm{b}}$ folds (axial traces trending left to right) and $\mathrm{F}_{\mathrm{c}}$ folc.s with axial traces parallel to pencil; looking west. Shore north of Storängen, Ängholmen. 9 b. F fold cut by amphibolite. Shore northeast of Norrnäs, Skärlandet. 9 c. Fc fold in amphibolite cut by SSE pegmatite and showing the relationship between earlier shear and pegmatite emplacemeat. Shore northeast of Norrnäs, Skärlandet.

(Fig. 8 b). The folds grouped under $\mathrm{F}_{\mathrm{b}}{ }^{\prime}$ probably belong to several sets initiated at different times in the course of the prolonged history of foliation shear in the migmatites and they may include some of the youngest structures in the rocks. 


\section{$\mathrm{D}_{\mathrm{c}}$ phase}

Folds of this generation are notably more open than any of the earlier-formed structures. They are decidedly asymmetrical (Fig. 9 c), sometimes with quartzofeldspathic veining parallel to their axial traces and in places show faint axial planar mineral growth. In isolation they are readily distinguishable from isolated $F_{b}$ folds by virtue of the fact that their axial planar traces are inclined to the dominant foliation trend (Fig. 9 b) whereas $\mathrm{F}_{\mathrm{b}}$ axial planar traces are parallel to the foliation (Fig. 9 a). In places where both sets of folds occur together the relationships between the foliation and their axial planes can be seen in the one outcrop (Fig. 9 a), although mutual interference where the two sets of folds are of the same order of size may obscure this relationship. Otherwise the two sets of folds are separable simply because one can be seen to refold the other (Fig. 10).

On horizontal outcrops $F_{c}$ folds appear as discontinuous asymmetrical structures of variable style and wavelength, ranging from a few centimetres to a metre or more across (Fig. $9 \mathrm{~b}$ ). Characteristically they have rounded, lobate hinges which may even be box-like (Figs. 9, 11) where single folds may show subparallel or slightly divergent axial traces (Figs. 9 a, b; 10 a).

The acute angle between the fold axial trace and the foliation trend implies a sinistral rotational sense inclined to the foliation (Fig. $10 \mathrm{~b}$ ) so that with the general easterly trend of the foliation in the Skåldo area, $\mathrm{F}_{\mathrm{c}}$ axial traces commonly trend $\mathrm{SE}$ with a moderately steep southwesterly dip of axial planes (Fig. 9 a). Where the foliation swings away from the normal E-W trend, the axial trace of $\mathrm{F}_{\mathrm{c}}$ folds correspondingly departs from the usual SE trend (Fig. $9 \mathrm{c}$ ).

It is probable that syntectonic or immediately post-tectonic pegmatite veins are associated with this deformational episode (Fig. $10 \mathrm{~b}$ ) and it appears that the emplace- ment of the quartzofeldspathic material, which is mostly autochthonous or parautochthonous, was directly controlled by shear or incipient shear strain more or less parallel to the fold axial traces. $\mathrm{F}_{\mathrm{c}}$ fold hinge zones have subsequently been used as sites of considerable pegmatite injection (Fig. $9 \mathrm{c}$ ).

In areas where $D_{a}, D_{b}$ and $D_{c}$ fold sets appear together the effects of mutual interference can be considerable. In spite of this the three sets can normally be discriminated provided reasonable care is exercised in applying the distinguishing criteria which include attitude, trend, style and crossfolding relationships (Fig. 10).

At some as yet undetermined time following $D_{c}$ there was a further episode of dolerite intrusion represented now by amphibolites which cut across $F_{c}$ fold structures with marked discordance (Fig. $9 \mathrm{c}$ ).

$\mathrm{D}_{\mathrm{d}}$ phase

The folds formed as a result of deformation during $D_{d}$ are similar in style to $F_{c}$ folds (Fig. $11 \mathrm{~b}$ ). They are asymmetrical and their axial traces, which are commonly parallelled by quartzofeldspathic veins, are inclined to the foliation trend. They are however separable from them because their axial traces trend at high angles to $\mathrm{F}_{\mathrm{c}}$ fold axial traces and also because they tend to be more regular and are frequently rectilinear. Where the two structures crop out together, $F_{d}$ folds can be seen to cause reorientation of $F_{c}$ folds and this rules out the possibility of the two sets being contemporaneous and conjugate. Often $\mathrm{F}_{\mathrm{c}}$ fold axial traces are very strongly curved by the later folds (Fig. $11 \mathrm{a}, \mathrm{c}$ ). Isolated examples of $F_{d}$ folds can be distinguished on the grounds that they appear to be genetically related to dextral shear couples inclined to the foliation. This means that because of the generally $\mathrm{E}-\mathrm{W}$ strike of the foliation in the Skåldö area, the traces of $\mathrm{F}_{\mathrm{d}}$ axial planes, which dip steeply, almost invariably have a 

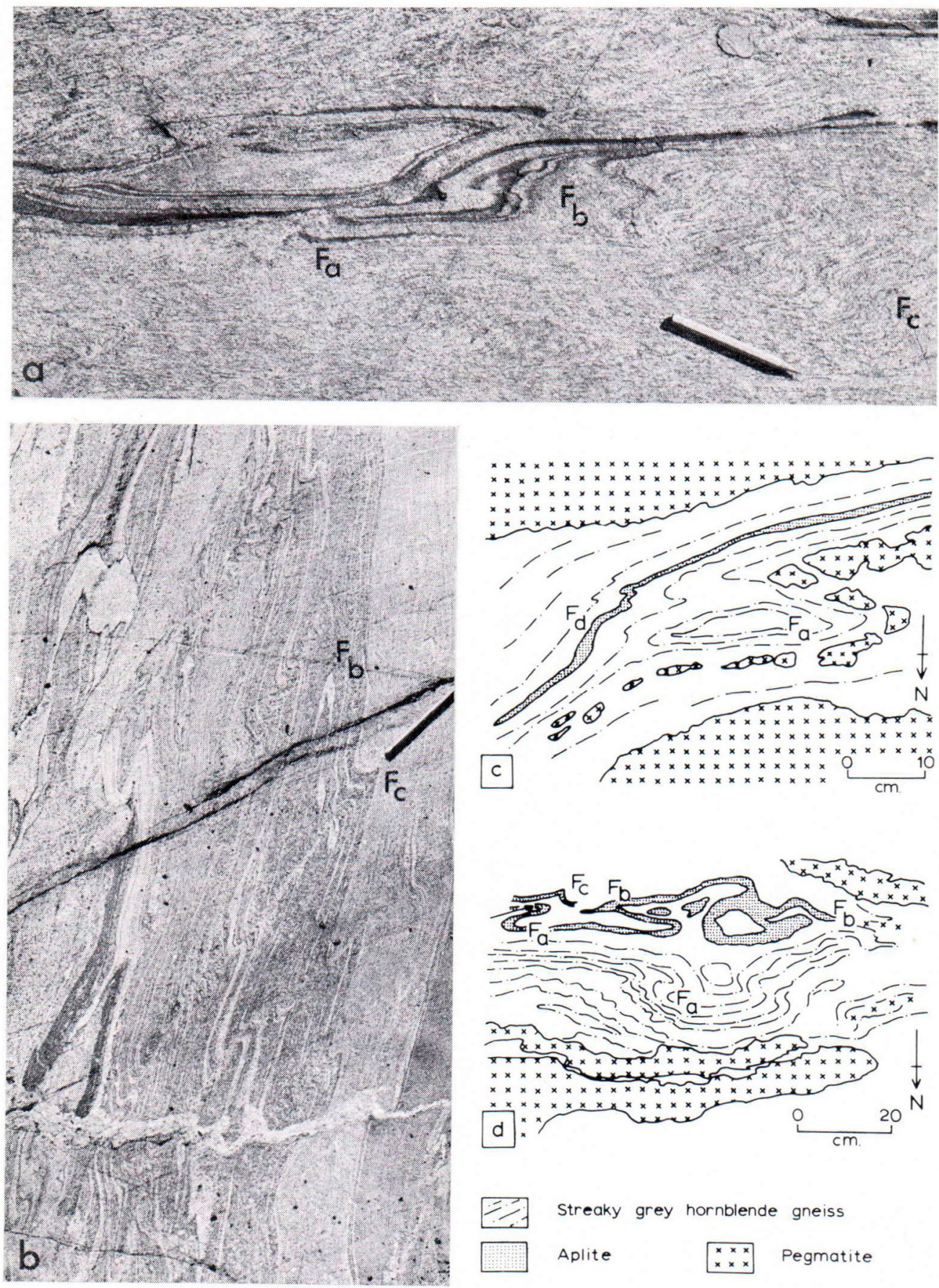

Streaky grey hornblende gneiss

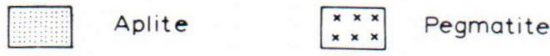

Fig. 10a. $\quad F_{a}$ and $F_{b}$ folds (axial trace parallel to foliation) and $F_{c}$ folds (axial trace parallel to pencil); looking south. Baggöhamn, near the kiosk, Skärlandet. b. $F_{a}$ and $F_{c}$ folds; looking west. Baggöhamn, near the kiosk, Skärlandet. c. Interference pattern resulting from $F_{a}$ and $F_{d}$ folds. North shore of Skärlandet, opposite Björnholmen. d. Interference patterns resulting from $\mathrm{F}_{\mathrm{a}}, \mathrm{F}_{\mathrm{b}}$ and $\mathrm{F}_{\mathrm{c}}$ folds. North shore of Skärlandet, opposite Björnholmen. 

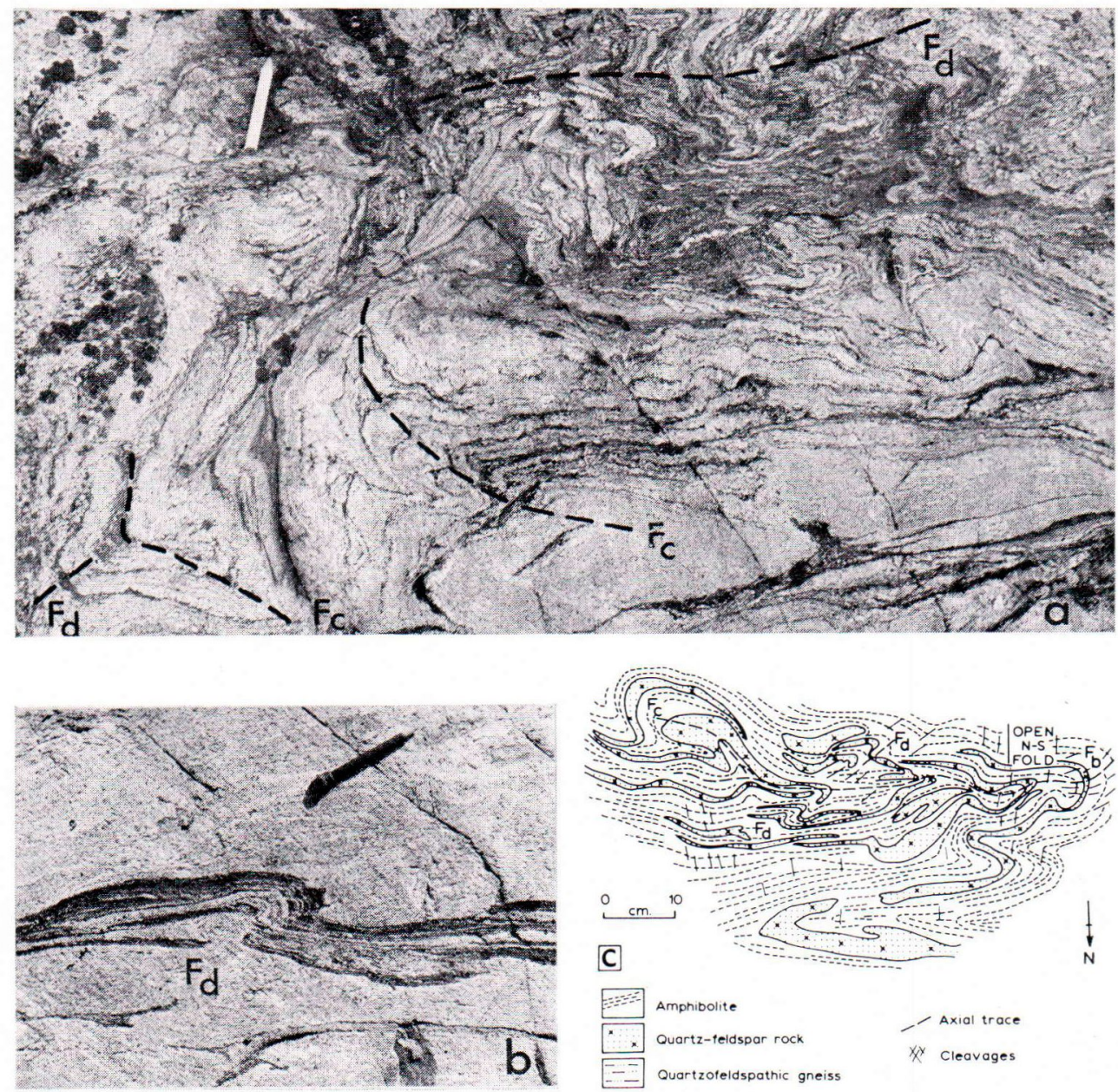

Fig. 11a. Refolding of $\mathrm{F}_{\mathrm{c}}$ folds by $\mathrm{F}_{\mathrm{d}}$; looking south. $\mathrm{F}_{\mathrm{d}}$ fold axial trace curved by late $\mathrm{N}-\mathrm{S}$ open folds. North shore of Notholmen, Skärlandet. b. $\mathrm{F}_{\mathrm{d}}$ fold; looking south. Baggöhamn near the kiosk, Skärlandet. c. Interference between $F_{b}, F_{c}$ and $F_{d}$ folds crossed by open N-S folds. North shore of Notholmen, Skärlandet.

$\mathrm{NE}$ trend, although in places this is sometimes altered by the effects of later folding (Fig. 12).

The stylistic similarities between the two fold sets may be a consequence of subsequent deformation, especially slip parallel to the foliation, which has modified them to the extent of obliterating all their characteristic features, apart from the axial planar mineralization which appears to be confined to $F_{c}$ folds only. Nevertheless future work may well show that $F_{d}$ folds have stylistic characters that considered alone are enough to set them apart from $\mathrm{F}_{\mathrm{c}}$ folds but it seems that in most cases their styles are indistinguishable, apart from the fact that where the two sets occur together and can be compared (Figs. $11 \mathrm{a}, \mathrm{c}$ ) some $\mathrm{F}_{\mathrm{d}}$ folds are seen to be more open (Fig. 12). They are thus separable at present only on the basis of axial planar trend or mutual cross-folding but where the two appear together the interference patterns produced are often extremely complicated 

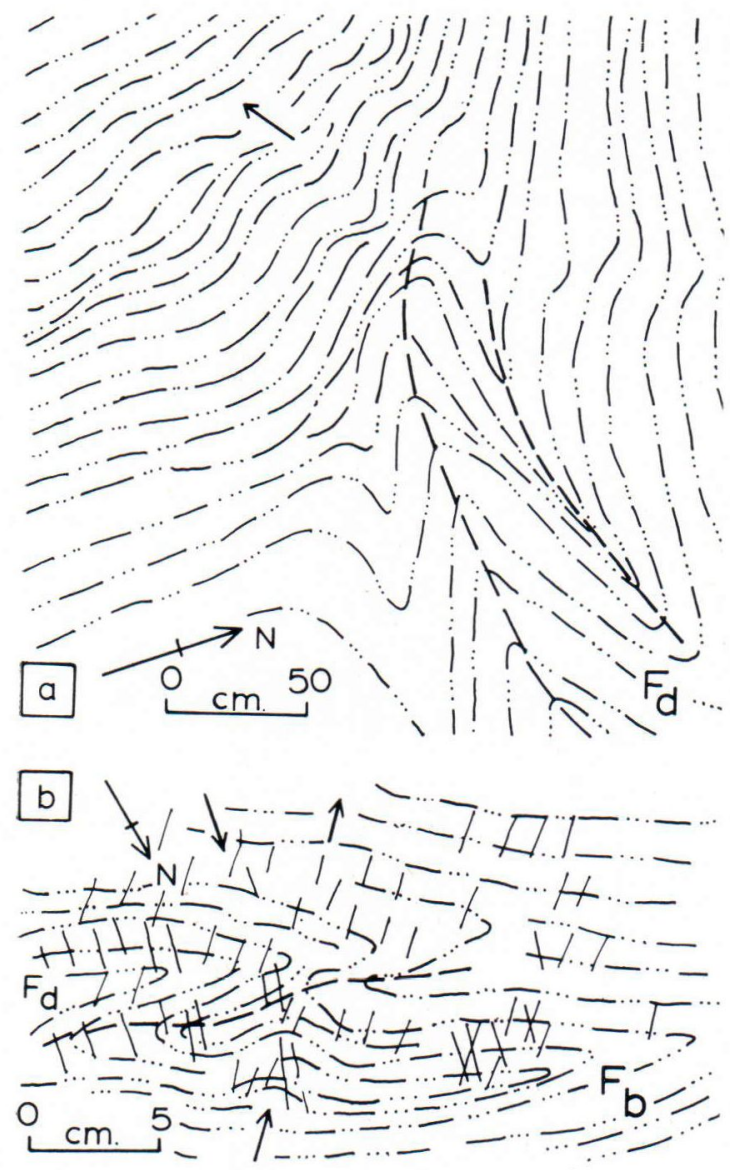

Fig. 12a. Folding of $F_{d}$ axial traces and $F_{e}$ folds by open $\mathrm{N}-\mathrm{S}$ folds in quartzofeldspathic gneiss. North shore of Notholmen, Skärlandet. b. Open $\mathrm{N}-\mathrm{S}$ folds with fracture cleavage affecting $\mathrm{F}_{\mathrm{b}}$, northeast-trending $\mathrm{F}_{\mathrm{d}}$ and $\mathrm{F}_{\mathrm{e}}$ in quartzofeldspathic gneiss. North shore of Notholmen, Skärlandet.

and then separation of the two sets requires considerable care (Fig. $11 \mathrm{a}, \mathrm{c}$ ).

$\mathrm{D}_{\mathrm{e}}$ phase

Following $\mathrm{D}_{\mathrm{d}}$ the migmatites seem to have responded to deformation in a somewhat more brittle fashion with the development of two sets of relatively open folds with incipient shears parallel to their limbs. The axial traces of these two sets of structures are often curved but on average trend respectively NNE and SE and the folds appear to be contemporaneous and conjugate, although on some outcrops it is possible to establish a sequential relationship where one direction is more regular than the other (Fig. 13). Whether or not a consistent cross-folding relationship exists remains to be determined and for the moment the two sets are treated together.

The close similarity of style coupled with their open form and relatively weak development often tends to result in complex, highly irregular interference patterns which may be difficult to decipher (Fig. $13 \mathrm{~b}$ ). This is because mutual interference precludes the development of axial planes which continue for more than a few centimetres so that on the outcrops axial traces are intermittant and irregular, changing direction over comparatively short distances. For this reason it is quite possible that more than one or two fold sets are involved in the interference pattern so formed.

In style the folds vary from open structures showing gently rounded hinges to asymmetrical kinks exhibiting sharp apices. There is a suggestion of slip parallel to one set of limbs in many cases and often these limbs form the locus of quartzofeldspathic material whose development, possibly in situ, was controlled apparently by local shear stress in much the same way as comparable veining associated with $\mathrm{F}_{\mathrm{c}}$ folds (Fig. $13 \mathrm{a}$ ).

$$
D_{\text {late }(f-n)} \text { phases }
$$

The occasional appearance of small chevron-type folds whose axial traces trend approximately ENE where the dominant foliation strikes approximately N-S may represent the effects of E-W subhorizontal slip. This slip would normally be parallel to the foliation with its general E-W trend in the Skåldö area, and would produce folds related to $\mathrm{F}_{\mathrm{b}}{ }^{\prime}$ and subsequent generations derived from later planar veins with axial 

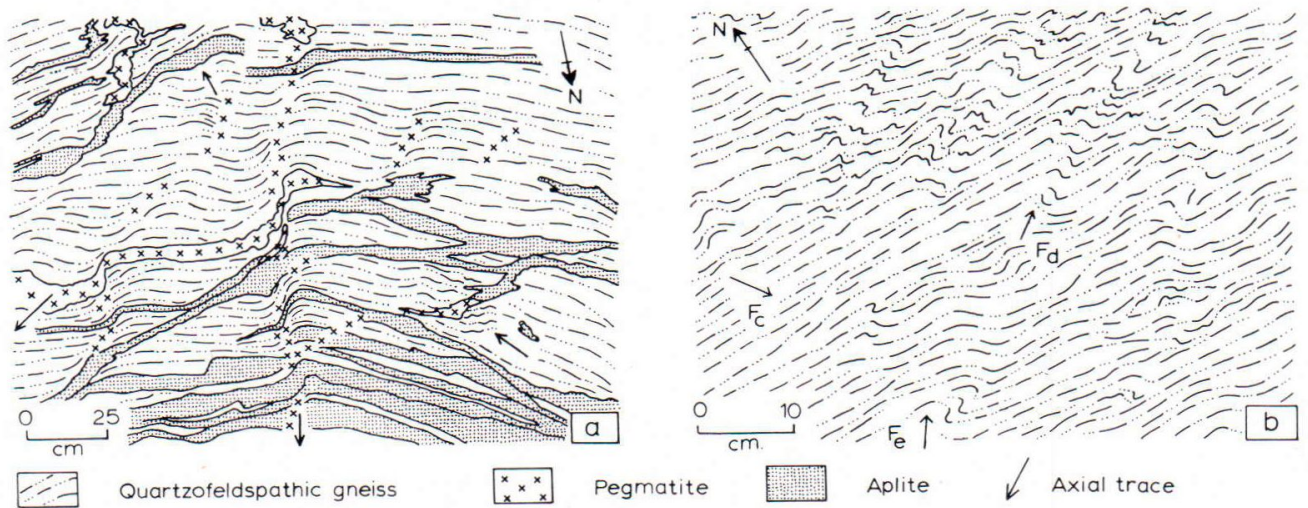

Fig. 13a. $\mathrm{F}_{\mathrm{e}}$ folds with development of quartzofeldspathic pegmatite parallel to some limbs. Shore northwest of Furuholm, Skärlandet. b. Interference pattern produced by $F_{e}$ folds and $F_{c}$. Northwest shore of Flackholmen.

planes parallel to the foliation. Where, however, the foliation departs from this E-W trend, folds of chevron type could be formed as a result of E-W slip-folding of the foliation, or of planar veins at high angles to the foliation (Fig. 14 a), where this is E-W.

The only examples of structures considered to have been produced by foliation folded in this way are small ( $1-2$ centimetres) folds with angular to rounded hinges (Fig. 14 a) and limbs that in places are slightly crumpled. The interlimb angle is in the region of $90^{\circ}$ and the folds tend to be comparatively isolated, separated by unfolded foliation for a distance equal to about twice their wavelength.

Fold structures demonstrably late in the sequence are those with axial planes trending $\mathrm{N}-\mathrm{S}$ (Fig. 14 b, c, d). These are mostly very open structures but they range from no more than gentle warps to moderately tight folds, usually with very rounded hinges, but sometimes showing hinges that are relatively angular. They impart a wavy effect to the banding where this would otherwise be more or less rectilinear in outcrop (Fig. $14 \mathrm{~d}$, e). They may represent more than one set of folds but if this is so these have not yet been distinguished. Apparently associated with the N-S trending axial planes is a moderately well developed north-trending, steep fracture cleavage which weathers out cleanly in amphibolite layers as a series of fine ribs. This structure is often fanned and the fanning may be the result of even later deformation. The axial planes of these structures, which appear to be flexural rather than shear folds, are subvertical.

Amongst the latest structural features are brittle structures such as conjugate shears which trend respectively NNE and SSE. These are steeply dipping surfaces apparently cutting all the folds but they are clearly not the latest structures in the deformational sequence because they are offset by shears parallel to the foliation. The relatively common N-trending steeply dipping, narrow, more or less rectilinear quartz lenses (Fig. 6 b) are possibly en échelon tension gash veins in zones parallel to the NNE and SSE complementary shears (Figs. 2 a, 5 a).

The latest deformation seems to have been the continuation of the foliation shear which may have proceeded from at least the time of $\mathrm{D}_{\mathrm{b}}$ throughout the deformational history of the migmatites. The progress of this move- 

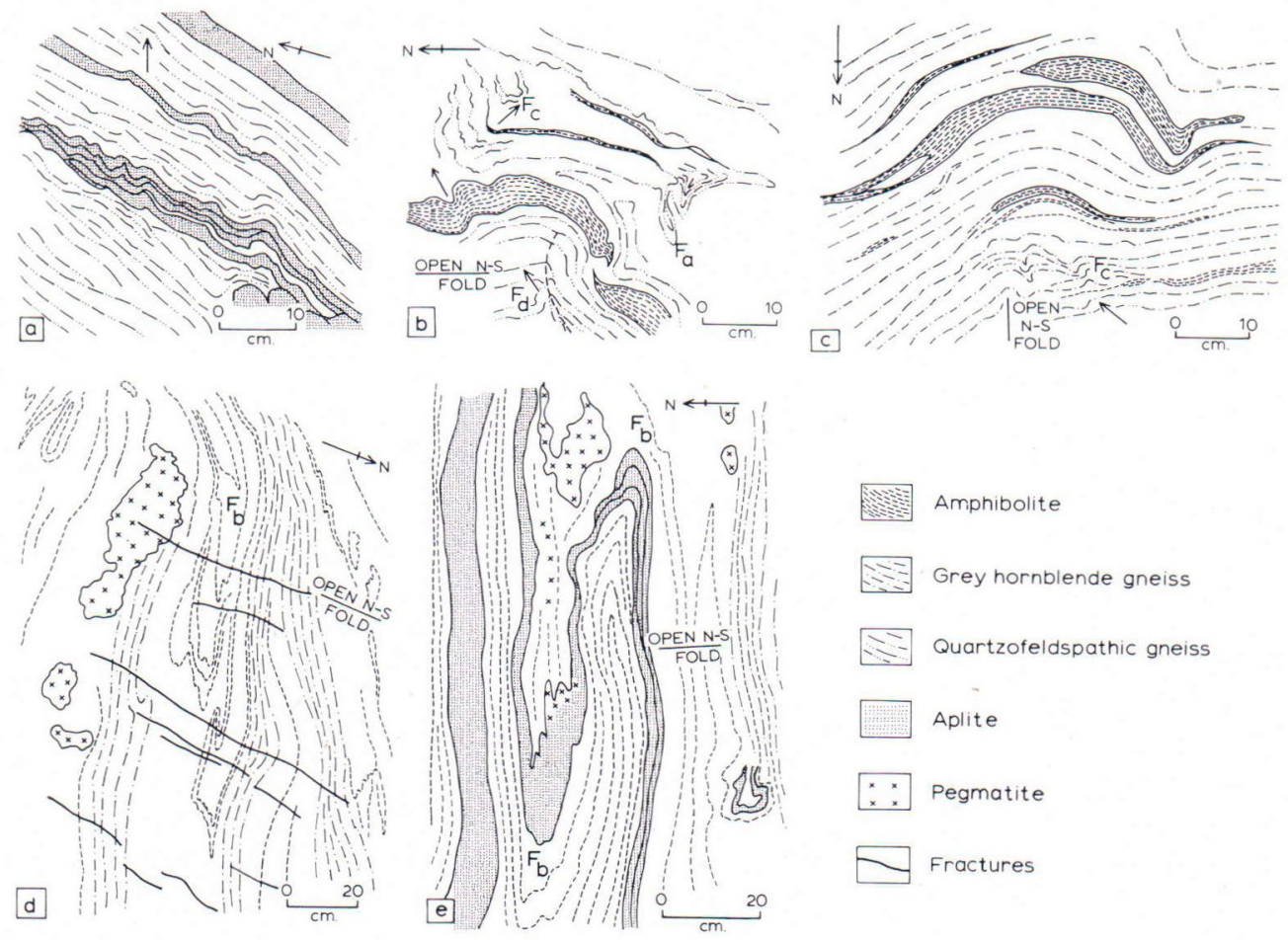

Fig. 14a. ENE chevron folds in $\mathrm{N}-\mathrm{S}$ trending foliation. North shore of Notholmen, Skärlandet. b. Complex interference pattern produced by $\mathrm{F}_{\mathrm{a}}, \mathrm{F}_{\mathrm{c}}$ and $\mathrm{F}_{\mathrm{d}}$ folds affected by $\mathrm{N}-\mathrm{S}$ folds. Norrnäs, Skärlandet. c. Interference between open $\mathrm{N}-\mathrm{S}$ folds and $\mathrm{F}_{\mathrm{c}}$ folds. Shore north of Storängen, Angholmen. d. Open $\mathrm{N}-\mathrm{S}$ warping of foliation folded by $\mathrm{F}_{\mathrm{b}}$. North shore of Skärlandet opposite Björnholmen.

ment can be monitored throughout the sequence because of its effect on planar structures such as dykes and veins emplaced from time to time during the developmental history of the migmatites (Figs. 5, 8) and it can be seen that the style of deformation became gradually more brittle, with a change from early structures with a flow fold aspect (Fig. $7 \mathrm{~b}$ ) through more angular shear folds (Fig. 14 a) to fracture, with offset parallel to the foliation, of the late conjugate shear zones.

Some open waves on horizontal outcrops appear to be the expression of inclined or recumbent folds gently plunging either east or west. An indication of their geometry can be determined on rare three dimensional exposures such as low cliffs or road cuts but these are so few that it has not yet been possible to determine the relationship of these structures to others in the sequence although they are thought not to be the result of late deformation. The inclined folds vary in style between relatively tight folds with interlimb angles of about $90^{\circ}$ to comparatively open structures but their horizontal profile is invariably very open.

\section{Discussion and conclusions}

The sequence of events shown by the migmatites of Skåldö is summarised in Table 1. This is considered to be only an outline of what could prove to be a much more complicated history and further investigation is likely to provide additional information and 
thus increase the certainty regarding points such as the relative time of event 10 and the number of fold sets involved in $\mathrm{D}_{\mathrm{e}}$. Nevertheless, it can be stated with reasonable confidence that the structures described and figured by Sederholm (1907) nearly three quarters of a century ago can be recognized and identified with distinct sets which can be placed in a consistent deformational sequence. Thus these migmatites record a history of polyphase deformation and metamorphic and igneous events all of which must be considered in a study of their petrogenesis.

The demonstration of a complex tectonic, metamorphic and igneous sequence such as the one shown here permits a stage by stage assessment of the progressive evolution of the deep levels of an orogenic belt. It also provides a sound basis for comparison with the successively developed products of other crustal levels and environments in the Svecokarelian orogenic belt. Furthermore, in this way the validity of correlation between these migmatites and the metasediments and metaigneous rocks of comparable age in other parts of the Baltic Shield can be tested and in addition it will be possible to determine how the style of tectonism, the degree of deformation, and the expression of metamorphic and igneous events varies throughout the orogenic belt.

The fact that the migmatites in the Skåldo area have been shown to form a complex rock unit whose characteristic mixed aspect resulted dominantly from repeated deformation and igneous intrusion indicates that the roles of metamorphic differentiation and partial melting at the present level of exposure, do not appear to have played as important a role here as that assigned to them in studies elsewhere (cf. Menhert 1968). Hence any examination of migmatite development in this region must not only take this into account, but must also take into account the time element which has so often played a relatively minor role in many discussions of migmatite genesis, particularly laboratory-orientated studies. The fact that sufficient time must have elapsed between successive phases of intrusion to allow folding and tectonic disruption to take place implies that time has not been insignificant and this bears out the thesis of Read (1957) that time as well as place are important factors in considering the genesis of migmatites.

With the establishment of a general structural framework, a study of metamorphism in relation to tectonics in these migmatites can be undertaken. This together with a study of the successively formed granitic veins throughout the area - their petrography, chemistry, geometry and mutual relations as well as ages from isotopic studies should lead to a fuller understanding of the genesis of migmatites, the crustal environments of their formation and the time spans of the processes involved. Linked with structural investigations it is hoped that this work will further elucidate the crustal history of the deeper levels of orogenic belts.

Acknowledgements - The authors are most grateful to Dr. M. Härme of the Geological Survey of Finland for his advice and help in selecting the area of study and they also wish to thank the residents of the Skåldö area, especially Mrs. A. Berglund of Pippings Folkskola, for their hospitality and kindness. The assistance of members of the Glasgow University Exploration Society is also much appreciated. In addition the authors wish to acknowledge financial assistance from the University Courts of the Universities of Glasgow and St. Andrews and from the Carnegie Trust for the Universities of Scotland towards the cost of publishing the illustrations. 


\section{REFERENCES}

Bowes, D. R. (1975) Scotland-Finland Precambrian correlation. Bull. Geol. Soc. Finland 47. $1-12$.

- Tectonics in the Baltic Shield in the period 2000-1500 million years ago. Acta Geol. Polonica (in press).

Gaàl, G., Koistinen, T. and Mattila, E. (1975) Tectonics and stratigraphy of the vicinity of Outokumpu, North Karelia, Finland. Geol. Surv. Finland Bull. 271. 67 p.

Härme, M. (1960) [Map of Pre-Quaternary rocks,], B1 Turku. The General Geological Map of Finland, 1:400 000.

- (1965) On the potassium migmatites of southern Finland. Bull. Comm. Géol. Finlande 219: 1-43.

Hopgood, A. M. (1971) Correlation by tectonic sequence in Precambrian gneiss terrains. Spec. Publs. Geol. Soc. Aust. 3: 367-376.

- (1973) The significance of deformational sequence in discriminating between Precambrian terrains. Spec. Publ. Geol. Soc. S. Afr. 3: $45-51$.

- and Bowes, D. R. (1972) Application of structural sequence to the correlation of Precambrian gneisses, Outer Hebrides, Scotland. Bull. Geol. Soc. Am. 83: 107-128.

King, G. and Grey, D. (1975) Glasgow University Exploration Society Expedition to Finland, 1974. University of Glasgow.

Laitala, M. (1973) [Map of Pre-Quaternary rocks], 2013 Jussarö. Geological Map of Finland, $1: 100000$.

Menhert, K. R. (1968). Migmatites and the origin of granitic rocks. Elsevier, Amsterdam.

Read, H. H. (1957) The granite controversy. Interscience Publishers, New York.

Sederholm, J. J. (1907) On granite and gneiss, their origins, relations and occurrence in the Precambrian complex of Fenno-Scandia. Bull. Comm. Géol. Finlande 23.

- (1967) Selected works: granites and migmatites. Oliver and Boyd, Edinburgh and London.

Welin, E. (1970) The Svecofennian orogenic zone in northern Sweden - a preliminary discussion. Geol. Fören. Förh. Stockholm 92: 433-451.

Manuscript received, July 23, 1975. 